\title{
A Study of Diction in the Indonesian Translation Binatangisme from George Orwell S Animal Farm
}

\author{
Maya Nur Lindasari \\ Universitas Negeri Surabaya \\ maya.17020154025.unesa.ac.id
}

Received: 22 ${ }^{\text {nd }}$ May 2021, Revised: $2^{\text {nd }}$ June 2021, Accepted: $23^{\text {rd }}$ June 2021

Email Correspondence: maya.17020154025.unesa.ac.id

\begin{abstract}
This article examined the Indonesian translation of the novel Animal Farm by George Orwell (1945). It was translated into Binatangisme by Mahbub Djunaidi, published in 1983. The diction of the novel was highlighted because diction was one of the important elements in the acceptability and accuracy words in literary works that need to be considered. There are three categories of dictions which analyzed in this article such as translation of pronoun, translation of cultural adaptation, and translation of terms and sentencing as proposed by Newmark (1988) and Nida (1964). The qualitative method in the form of content analysis was applied to obtain information data that are objective, systematic, and descriptive quantitative about what appears in the choice of diction. The data were collected through close reading which highlighting or giving comments in the forms of monologues and dialogues as well as phrases and sentences, while the data analysis was compared between the source language and the target language. As the result, the translation was near to the target language culture. Mostly, the translator tends to describe the meaning through detailed explanation and used more specific meaning words.
\end{abstract}

Keywords: literary works, diction, translation

\section{INTRODUCTION}

Translator is as a slave, the servant of the source text. Translators are like gardeners, who work on other man`s field, they are maintaining the vineyard but the wine belongs to the landlord." As the imagery proverb stated by John Dryden in Bassnett (1993), whoever the translators are, the author remains the fame. Robinson (2003, p.50) stated that translation is always a smart act-even if it seems the least conscious or analytical. The translation is a very complex process that requires a rapid, multilayered analysis of the semantic domain, syntactic structure, sociological and psychological responses of readers or listeners, and cultural differences. Like all languages used, translation is constantly innovative and brings a new thing.

The existence of translators has an important role in literature as a connector between one culture and another (Cragie \& Pattison, 2018). Someone can easily understand the point and the purpose of the message conveyed by the author using translating the source culture into the target culture. Every message that is delivered must be following a clear purpose so there is no misunderstanding between translators and the readers. In addition, (Cragie \& Pattison, 2018) explain 
that the role of translation in the field of scientific knowledge, society, and culture is very important because translation can be interpreted as translating the words, phrases, and sentences with considering meaning, style, and cultural nuances.

In a process of translation, some aspects need to be considered such as diction, the language of style, grammatical and conventional lexical, depending on the topic and the situation, the elements of the text content, expectations readers, their point of view, and presumptions of the translator (Newmark, 1988:5)

The novel is one of the branches of literary works, it does not only show the story as the author`s imagination but also often shows the principles and ideology of the author. In the novel, discussing diction is very interesting because diction and the meaning are closely related to each other (Nirwana, 2014). In addition, the author always tries to direct the reader to images of the reality of life through stories in it. Each author has his language style that can differentiate from other authors. Although a novel in its appearance is not too bound by rhymes, lines, and stanzas which are usually used in poetry. The author uses certain unique word choices and characterizes them. Nababan (2007) points out that a translator must have good context textual, cultural, scientific, strategic, and transfer competencies. Translators are not only required to have good language competence, but also cultural knowledge so, that the translation results can be accepted. Hence, translating a novel is certainly not an easy thing, especially if in the source language and target language there are cultural differences.

Diction is the writer`s choice of words. Diction is one of the important elements because the acceptability and accuracy words in literary works need to be considered (Passandaran, 2019). The accuracy and suitability of word selection/ diction depend on its meaning because a word can cause various meanings. The point of accuracy, acceptability, and readability should be used as guidelines in choosing words (Keraf, 2009:114-115). In line with Keraf (Kenney, 1996:60) stated that diction is meant simply the author`s choice of words, also the author`s way of using language and arranging words into such larger units as sentences. Therefore, as a translator, the unclear meaning of words, ideas, and meanings is an obstacle that is often faced when translating literary works. Especially if one word has more than one meaning so, it will influence the choice of diction. From all the statements above, the use of diction has an important role in literary works. It can be useful for the readers to interpret the meaning of the sentences. In addition, Kenney (1996:75) explains that sometimes words come so easily that we can find no difficulty in expressing what we want to share. At other times, we are striking out word after another as we search for the best word to convey our thoughts. The most important thing is the implicit meaning in every word that reflects an idea. The author uses diction to choose the right word to create a certain meaning in a literary work. With that diction, the author can compose word for word in his writing. This is later going to be discussed as the focus of this article.

Newmark (1988:45) points out that the main problem of translating has always been whether to translate literally or freely. Furthermore, Newmark already stated that there are eight methods of 
translation which are divided into two categories; near to the source language emphasis (Word-forword translation, Literal translation, Faithful translation, and Semantic translation) and near to the target language emphasis (Adaptation, Free translation, Idiomatic translation, and Communicative translation). The easier way to understand the translation is near to the source language because a translator used some aspects like expression, language style, diction, and so on. In line with Newmark, A.Nida (1964) claims to define translation as the process of reproduction of words that are equivalent in meaning and structure to the target language.

Several studies related to literary translation has been done in recent year, such as "Howdunnit ? The French translation of Australian cultural identity in Philip McLaren`s crime novel Scream Black Murder/Tuer d'Aborigineses" by Reed (2016). This study explains that the difficulties of translating cultural terms will affect the translator in choosing the strategy of translation according to his/her perception, in line with literary translation can show culture from the source culture into the target culture. Tuominen`s article (2019), entitled "Experiencing translated media: why audience research needs translation studies", points out that translation certainly transforms the media texts to an integral factor in shaping the audiences` understanding. Marin-Lacarta (2019) in her article "Characteristics of a digital literary translation publisher: revisiting Bourdieu`s mapping of the publishing field, analyze a case study about the issue of literary translation in e-book format according to Bourdieu`s observation. An interesting study by Ahmed Saeed Balla \& Gumaa Siddiek (2017) entitled "Complications of Translating the Meanings of the Holy Qur'an at Word Level in the English Language in Relation to Frame Semantic Theory", emphasizes that it is a challenging task to translate Qur'an. Meanwhile, not all Muslims understand Arabic. As the result, the linguistic background became the most factor that affect of translating Arabic-English language to the translator`s ability than the cultural background/knowledge

Another study related to translation, "Translating national allegories: the case of crime fiction" by Rolls et al., (2016), discussed three major points; the translation of crime fiction, the articulation of the national in crime fiction, and the translation of national allegories. Nanquette`s article (2017) entitled "Translations of modern Persian literature in the United States: 1979-2011", examines the practice of translation from modern Persian literature into English in the U.S over thirty years, describing where the translation field intersects with the political, academic, and literary field in the case of Persian texts.

According to Newmark (1988:4), a translation is never finished. It means that there are still many possibilities to other translators trying to translate on the same field continuously. For instance, Animal Farm has been already translated by three translators which have a different style in the translation results. In 1983, Mahbub Djunaidi translated the title of Animal Farm with "Binatangisme" later on, Prof Bakdi Soemanto translated the novel with same the original title "Animal Farm" then, J. Fransiska. M used the same title "Animal Farm" to translate the novel in 2002. Possible translators 
inside translate the title Animal Farm be an Animal Farm to give hidden meaning to the reader so that readers are more curious about the title he translated or also maybe the translator adapts with a cultural context so as not too rude and possible translator keep the authenticity of the title is more inclined to the direction of the origin or for retains cultural references to text sources, cultural values, and as cross-cultural learning.

This article will be examined based on the following research questions: (1) What are the dictions found in the Indonesian translation Binatangisme from George Orwell`s Animal Farm? (2) What are the meanings of the dictions in the Indonesian translation Binatangisme from George Orwell`s Animal Farm?

\section{RESEARCH METHOD}

The research method in this study is qualitative in the form of content analysis that is objective, systematic, and descriptive quantitative about what appears in the choice of diction. This study has the characteristic of analyzing the results of the translation result. The method is based on the opinion of Zuhdi (1993: 6) which states that content analysis techniques are used to understand symbolic messages in the form of documents, paintings, dances, songs, literary works, articles, and so on in the form of unstructured data. Therefore, following the research questions, the study used the qualitative method because it was studied a verbal text in the form of writing taken from the choice of diction so that the entire of both original novel and its translation in Indonesian could be studied properly.

The data is taken from chapter I to X. The data source was taken from two sources. The first one is from the original novel Animal Farm by George Orwell as a source language. Then, the second one is from the Indonesian translation version as the target language. It was translated by Mahbud Djunaidi and was published in 1983 entitled Binatangisme. The data of this study are in the forms of monologues and dialogues among the characters as well as phrases and sentences which contain several dictions

This study took several steps, including reading, listening, identify, and classify the dictions in the novel In collecting the data, this study was required to do a close reading on both literary works which highlighting or giving comments in each of diction, in the form of dialogues, epilogues, and direct-indirect speech between characters.

\section{FINDINGS AND DISCUSSION}

Diction plays an important part in expressing differences in meaning. Differences in authorship, age, socio-cultural background, education, and religion give color to the differences in diction. The readers will precisely understand if the writing has an accuracy of words in expressing an idea and the suitability between words and contexts

The accuracy of the dictionary can create certain nuances in the reader's mind, especially in 
translation works, where the cultural context may be completely unfamiliar to them. Of course, every translator tries to find out the exact words so, the readers be able to comprehend the translation results in a way that they can explore various kinds of literature from other countries and cultures. The issue of diction is not a simple one. The accuracy of choosing words or diction to express an idea is expected that the function obtained will be under with the objectives to be achieved. The result of this study finds the choice of diction in 3 categories; the translation of cultural adaptation, the translation of pronouns, and the translation of terms and sentencing.

\subsection{The Translation of Cultural Adaptation}

Newmark (1988) explains that the use of a componential analysis in translating cultural words is that the readers are unlikely to understand; whether the component analysis is accompanied by an accepted functional, translation, equivalent, cultural equivalent, transference, etc. It will depend on the particular text-type, the requirements of the readers, and the importance of the cultural word in the text.

The following example below will be discussing further explanations by the strategy of cultural adaptation as in:

a) "Tuan Jones pemilik peternakan "MANOR". Malam itu ia baru saja mengunci

Mr.Jones of the Manor Farm night had locked

kandang ayam...."(h. 1)

the hen-houses.....

'Mr.Jones, of the Manor Farm, had locked the hen-houses for the night, ......'(p.1)

The words 'Mr. Jones' is translated into Tuan Jones. The word 'Mr' refers to the older or respected person. In Indonesian culture, it is commonly used Pak, Bapak. The translation of 'Mr` into Tuan is the cultural adaptation in the target text. Similarly, in the next paragraph, the translator also translated 'Mrs` as Nyonya. The word Nyonya shows the hierarchy in terms of distance and age as in:

b) “..taplak meja berwarna hijau milik nyonya Jones.."

tablecloth green Mrs. Jones's

‘an old green tablecloth of Mrs.Jones`s (p.10)

Meanwhile, the word 'hen-house` is translated into kandang ayam. The meaning in Indonesian is rumah ayam. The word rumah (house) is a living place for humans, it is not a living place for an animal such as hen. So, the translator chooses to use the word kandang in the target culture because it means a living place for the animals. Sometimes, he also used the word kandang to translate 'farm buildings` (c), 'the big barn` (d), also refers to the word 'the block' (e) as in

c) “..terdengarlah suara berisik di antero kandang.” (h.1)

$$
\text { a fluttering through farm buildings }
$$

$\therefore$..a fluttering all through the farm buildings` (p.10) 
d)"Sesudah menaikkan bendera, binatang-binatang itu

After hoisting the flag all the animals

berbaris $\underline{\text { menuju }}$ kandang utama...." (h.36)

trooped into the big barn

'After the hoisting of the flag all the animals trooped into the big barn...."(p.10)

e)“..menggelepar dan mati dalam setahun ini di luar kandang."

lives within a year out the block

'.....lives out at the block within a year.' (p.3)

f) "Burung ketilang bersiul lagi itu di pagar, burung dara menggeram

The blackbirds whistled it in the hedges the pigeons cooed

dengan lagu itu.Di bengkel tukang besi, lagu itu mengalun. Bahkan,

it the din smithies the tune

lonceng gereja mengikuti irama itu!" (h.47)

the church bells

The blackbirds whistled it in the hedges, the pigeons cooed it in the elms, it got into the din of the smithies and the tune of the church bells.' (p.12)

Next (f), the term `blackbirds` is translated to be burung ketilang. If it is literally translated into Indonesia, it will be burung hitam. The translator used the specific animal because there is some kind of birds that are black in the target culture. In the target culture, burung ketilang is called a sootyheaded bulbul which is not black, some part of the body is grey and the hairs on his buttocks is orange.

\section{g) "Adalah mustahil, $\quad$ kata Napoleon; mengubur jasad Boxer di petemakan,}

It had not been possible he said bring back their lamented on the farm,

$\underline{\text { namun }} \underline{\text { ia }}$ sudah perintahkan bikin karangan bunga ukuran besar dari daun dadap

but he had ordered a large wreath from the laurels

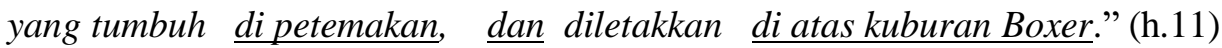

in the farmhouse and sent down on the Boxer`s grave

'It had not been possible, he said, to bring back their lamented comrade's remains for interment on the farm, but he had ordered a large wreath to be made from the laurels in the farmhouse garden and sent down to be placed on Boxer's grave.`(

The laurel (g) often used as a symbol of victory, worn on the head. For instance, the picture of Julius Caesar, the last Roman dictator who was wearing a laurel wreath in his head symbolize his honour and victory. In the above paragraph, the term ‘the laurels` is translated into daun dadap. The literally meaning in Indonesian is daun salam which is one of the most condiments used in every Indonesian culinary. While the translation is daun dadap which is a herbal leave that has many benefits to body health. Often used as hedges and thickets. The translation of 'the laurels' into daun 
dadap is the cultural adaptation in the target text since those leave will be made into large wreaths.

h)".... Kau akan dapat gaplek dan $\underline{\text { rumput kering." }}$

You will have oats and hay

'...You will have all the oats and hay you want.' (p.6)

i)"...pohon angsana yang tumbuh di kaki kandang..."

elm tree at foot orchard

'....an elm tree at the foot of the orchard...' (p.21)

Furthermore, it was found the choice of diction in term of food. The excerpt (e) shows that the translator used the word gaplek to translate `oats`. If it is literally translated, 'oats` means haver which is more common in the subtropical region. Then, Gaplek is a kind of dish from cassava, it can be made into tiwul rice. This food is very popular in Gunung Kidul, Yogyakarta. However, gaplek is more common in Indonesian culture. In excerpt (i), 'elm tree` is translated into pohon angsana. 'Elm tree` or 'ulmus famili ulmaceae' is a deciduous tree and soft-hardwood from Central Asia, while pohon Angsana ('Angsana tree') or 'pterocarpus indicus` or known as sonokembang is a high-quality wooden tree which is commonly grown in Indonesia.

\subsection{The Translation of Pronoun}

Personal pronouns have different nuances in each country. Pronouns that are acceptable in one culture may not be accepted and are equivalent to another culture. For instance, the word 'you' refers to a neutral addressing word in English. However, Indonesian culture is not the case. It can be used kau, engkau, kaти, dirimu (Indonesia-investments.com, n.d.).

The following example below will discuss further explanations of the translation results in personal pronouns as in

a) "Dan engkau, hai ayam-ayam betina!......" (h.10)

And you hens.....

`And you hens,......'(p.2)

b)"Ah, sahabat Boxer!...." (h.11)

You Boxer

'You, Boxer,......' (p.3)

c) "Apa mereka meneteskan susu? Tidak." (h.8)

$\mathrm{He}$ give milk not

'He does not give milk,......' (p.2)

d)" En toch! Makhluk manusia itu juragannya semua bangsa binatang" (h.8)

he is lord all animals

'Yet he is lord of all the animals.' (p.4)

e)" .....serta cecunguk cecunguk sebangsanya." (h.10)

and his men 
and his men.`(p.2)

f)" ..ketiga pentolan itu memang menghadapi sikap- sikap tolol...." (h.20)

they met stupidity

‘...they met with much stupidity....'(p.2)

The word 'you` in excerpt (a) is literally translated into engkau. In Indonesian, the word engkau means those who are spoken to, who are addressed (used for people of the same or lower position), are also used to pray to God. If we talk to our parents, like `Mother, where are you `(engkau)? it will be considered impolite. In daily life, engkau, kaulah is rarely used as a conversation usually, the word engkau is found in the field of art or literature. In the target text, it was found that engkau is written 4 times. Also, the translator uses dikau, kaulah as in:

g) “Hiduplah dikau, sahabat Napoleon

Comrade Napoleon!

Kauhlah itu, sahabat Napoleon" (h.109)

Comrade Napoleon!

‘Comrade Napoleon!' (p.28)

Instead of translating 'you' into engkau, kamu, kau, the personal pronoun 'you' in the excerpt (b) is translated into Ah, Sahabat ('friend'). In Indonesia, sahabat means a best friend who will always help in any situation and condition, or try to find any solution when there's a problem. The translator uses sahabat to indicate that the animal has closeness each other.

The word he in the excerpt (c), if it is literally translated into Indonesian, it will be dia, ia used as the third-person singular. While the translator translated it into mereka ('they') which is used as the third-person plural. Next, (d) 'he' is translated it into makhluk manusia (human) because it is referred to Mr. Jones who is hated by all animals. Then, 'his` (e) is translated into cecenguk cecenguk sebangsanya. In indonesian, cecenguk or cecunguk can be described as an unprofessional gangster or bandit. It is indicates that Mr. Jones has incompetent men. In excerpt (f), the word 'they` is translated into ketiga pentolan. They refer to Napoleon, Snowball, and Squelar. Three of them are the main antagonist characters in the novel who had power to control other animals. The word pentolan can describe a leader who had the power to control all of the activity over their fellow.

\subsection{The Translation of Terms and Sentences}

The translator tends to describe the terms and sentences rather than to find suitable and equivalent words. It makes his translation result to be slightly longer. The following example below will discuss further explanations of translation of terms and sentences as in:

a) “Kehidupan seekor binatang adalah mata rantai ratap kesedihan yang

The life an animal is

sambung bersambung, tak putus- putusnya. Kehidupan seekor binatang adalah

misery The life an animal is


kehidupan perbudakan! Camkan kata-kataku ini: perbudakan!

Slavery

slavery

Dan itulah fakta, kalau kalian mau tahu. Itulah kebenaran yang telanjang bulat!" (h.6)

this is the truth this is the the plain truth

'The life of an animal is misery and slavery: that is the plain truth.' (p.2)

b) "Karuan saja, apa pun yang terjadi, mutlak perlu menutup-nutupi kenyataan yang ada necessary conceal fact

terhadap dunia luar. Binatang boleh lapar, boleh loyo, boleh mata kuyu, from world outside

boleh gusi bengkak, tapi kesemuanya itu mesti disembunyikan supaya tidak ketahuan

'It was vitally necessary to conceal this fact from the outside world.' (p.22)

c) "Kincir sudah hancur berantakan!

the wind was in ruins

Kincir $\quad$ sudah jadipuing!

the wind was in ruins

Kincir sudah ambruk seperti ketimpa tujuh lapis langit

the wind was in ruins

Kincir $\quad$ sudah ............ tiada lagi kincir!(h.81)

the wind was in ruins

d). 'The windmill was in ruins.` (p.21)

From the excerpts (a), (b), (c), it was found that the translator explains it with detailed description. Also, the translator borrowed the other language as in:

d)“Jadi, binikolektip, naudzubillahi min dzalik!.”

However, never fully believed

'However, these stories were never fully believed (p.12)

The translator translated the sentence (d) into Arabic language binikolektip, naudzubillahi min dzalik. It is commonly said Naudzubillah Min Dzali" which means 'We take refuge in Allah from that bad thing`. Culture comes from habits. Culture is not only in the form of customs or art. One of the cultures is the language because language is always used by humans as social creatures to communicate. Muslims, especially in Indonesia, have their own habits in responding to something. When responding to something they usually say words from Arabic which is the place where Islam originated. The words used are usually embedded with the name Allah. The use of each word may be different but with the same goal of remembering Allah SWT. This sentence is often used when seeing something bad. 


\section{CONCLUSION}

The translation result of Binatangisme as translated by Mahbub Djunaidi have a proper readability level. As Newmark said, the work of literary translation is divided into two categories; near to the source language (word-for-word translation, faithful translation, semantic translation, literal translation) or near to the target language (free translation, adaptation, communicative translation, idiomatic translation). The translation of Binatangisme is closer to the target language culture by maintaining literary effect. Also, the translator shows the meaning through detailed description and uses more specific meaning words. Since it is a satire novel, the translator`s success brings the nuances into the target culture perfectly.

This study suggested to the readers to improve their ability in translating literary works. It is because translation makes a big influence on humanity for better understanding the literature diversity in the world. Hopefully, this study may help the reader in expending their knowledge, in case of understanding the diction in the English - Indonesian novel.

\section{REFERENCES}

A.Nida, E. (1964). Eugene A. Nida - Toward a Science of Translating_With Special Reference to Principles and Procedures Involved in Bible Translating (First). Adler's Foreign Books Inc.

Ahmed Saeed Balla, A., \& Gumaa Siddiek, A. (2017). Complications of Translating the Meanings of the Holy Qur'an at Word Level in the English Language in Relation to Frame Semantic Theory. Advances in Language and Literary Studies, 8(5), 172. https://doi.org/10.7575/aiac.alls.v.8n.5p.172

Bassnett, S. (1993). Comparative literature: A Critical Introduction (first). Blackwell.

Cragie, S., \& Pattison, A. (2018). Thinking English Translation. In Thinking English Translation (first). Routledge. https://doi.org/10.4324/9781315229478

Indonesia-investments.com. (n.d.). How to Act Indonesian. Www.Indonesia-Investments.Com. Retrieved April 8, 2021, from https://www.indonesia-investments.com/business/working-living/howto-act-indonesian/item299

Kenney, W. (1996). How to Analyze Fiction. Monarch Press.

Keraf, G. (2009). Diksi dan Gaya Bahasa. PT Gramedia Pustaka Utama.

Marin-Lacarta, M. (2019). Characteristics of a digital literary translation publisher: revisiting Bourdieu's mapping of the publishing field. The Translator, 25(1), 27-41. https://doi.org/10.1080/13556509.2018.1543566

Nanquette, L. (2017). Translations of modern Persian literature in the United States: 1979-2011. The Translator, 23(1), 49-66. https://doi.org/10.1080/13556509.2016.1227530

Newmark, P. (1988). A Textbook of Translation. In The Bible Translator (Vol. 40, Issue 3). PrenticeHall. https://doi.org/10.1177/026009358904000310

Nirwana. (2014). An Analysis of Diction Used in Lisa See`s Novel "Dreams of Joy" (Issue 
40300111033) [Alauddin State Islamic University]. http://repositori.uin-alauddin.ac.id/6372/

Passandaran, Y. M. (2019). Diction in Emily Dickinson's Poems. CLLIENT ( Culture, Literature, Linguistics, ENglish Teaching ), 01(01), 49-64. https://ojs.unsiq.ac.id/index.php/cllient/article/ view/659

Reed, S. (2016). Howdunnit? The French translation of Australian cultural identity in Philip McLaren's crime novel Scream Black Murder/Tueur d'Aborigènes. The Translator, 22(2), 157-175. https://doi.org/10.1080/13556509.2016.1184880

Robinson, D. (2003). Becoming a translator: An introduction to the theory and practice of translation: Third edition. In Becoming a Translator: An Introduction to the Theory and Practice of Translation: Third Edition (second). Routledge. https://doi.org/10.4324/9780203425961

Rolls, A., Vuaille-Barcan, M.-L., \& West-Sooby, J. (2016). Translating national allegories: the case of crime fiction. The Translator, 22(2), 135-143. https://doi.org/10.1080/13556509.2016.1205707

Tuominen, T. (2019). Experiencing translated media: why audience research needs translation studies. The Translator, 25(3), 229-241. https://doi.org/10.1080/13556509.2019.1615694 
